Volume: 14 Issue: 2 Year: 2017

\title{
The level of satisfaction of primary health services evaluation about Syrian women refugees who took refuge in the town Bucak
}

\author{
Mümin Polat ${ }^{1}$ \\ Gülcihan Aybike Dilek² \\ Canan Demir Barutcu ${ }^{3}$ \\ Serkan Köksoy ${ }^{4}$
}

\begin{abstract}
This study, women who took refuge in the Syrian town of Bucak in order to investigate satisfaction to basic health services by women and 43 is performed. The participants ' socioeconomic status, number of children and birth hospital were assessed with the questionnaire created by the researchers to assess the service questions. The number of data in statistical analysis percentage and Chi square test was used. The average age of women who participated in the research $4330.19 \pm 3.12$ were found. 34 women $(74.4 \%)$ hospital conditions described as good. 22 women in terms of the provision of health services (52.2\%) stated he didn't see a difference between Syria and Turkey. The supply of the drug in 30 women $(69.8 \%)$ expressed in the form of comfortable, I can assure you. The average number of children was 2.7 (max:7) as were found. In our country the number of the mother who gave birth 38 (88.4\%). Women $26(60.4 \%)$ are not using any family planning method. Their children have not been immunised mother, who had number $5(11.6 \%)$. Women $97 \%$ of the country has stated that he wants to return to. The study found that refugees are lacking in receiving basic health services. Refugees' family planning, vaccination implementation deficiencies need to be addressed. It is thought that the attitudes of mothers who have not vaccinated in order to prevent infectious diseases should be changed.
\end{abstract}

Keywords: Syrian women refugees; primary health care; war.

\section{Introduction}

A significant part of the Syrians who were in difficult conditions due to the civil war in Syria in March 2011 had to leave their countries. The number of people who left the country due to the ongoing civil war in Syria exceeded 2 million. According to the United Nations (UN) data, 4.6 million people, and according to Syrian sources, at least 7 million people had to move within the country. It is estimated that an average of 7000 people pass through neighboring countries from Syria every day (USAK, 2013). Turkey, which has a 877 kilometer border with Syria, is at the head of the countries most affected by the wave of migration due to the large number of refugee flows. Turkey has been a safe harbor in terms of Syrian asylum seekers who continue to come to Turkey extensively since the first days of the chaos that has been living for about 6 years (Altındiş, 2013, s. 65). The crisis in Syria forced all Syrian people, especially Syrian women and children, to live on

\footnotetext{
1 Assist. Prof. Dr., Mehmet Akif Ersoy University, Faculty of Health Sciences, Burdur, mpolat@mehmetakif.edu.tr

2 M.Sc. Student, Mehmet Akif Ersoy University, Faculty of Health Sciences, Burdur, aybikedilek15@gmail.com

${ }^{3}$ Assist. Prof. Dr., Mehmet Akif Ersoy University, Faculty of Health Sciences, Burdur, cdemir@mehmetakif.edu.tr

${ }^{4}$ Lecturer, Mehmet Akif Ersoy University, Faculty of Health Sciences, Burdur, skoksoy@mehmetakif.edu.tr
} 
Polat, M., Dilek, G. A., Demir Barutcu, C. \& Köksoy, S. (2017). The level of satisfaction of primary health services evaluation about Syrian women refugees who took refuge in the town Bucak. Journal of Human Sciences, 14(2), 1861-1864. doi:10.14687/jhs.v14i2.4457

extremely unfavorable conditions. The confusion and war environment in the country has made life difficult both in the country and in the countries where they are seeking refuge. The Republic of Turkey is investing heavily in labor and money to host the Syrians, especially in the border towns that are open to the public. According to the UN High Commissioner for Refugees (UNHCR) dated April 21, 2014, Women and children constitute more than 50 percent of the 2,704,812 Syrian population who left their country in the Syrian civil war and settled in Turkey, Iraq, Lebanon, Jordan and Egypt. Like men, women also escape the tyranny they live in their countries; But unlike men, they need special protection (UNHCR, 2011). The fact that women are much more adversely affected than men in this process is also supported by various researches. Gender differences manifest themselves during the war. Women in general; Gender-based discrimination, oppression and persecution resulting from social and cultural prejudices, abandonment of countries to escape persecution and oppression, such as sexual abuse, sexual violence, domestic violence, and immigration to another country, harmful practices that disrupt the physical and mental health associated with traditions They are obliged (Baydar, 2012; Koruk, 2013). In Turkey, which is at the head of the countries where they are seeking refuge, it was not possible to reach a research study on the basic health services provided. Therefore, the difficult circumstances of the Syrian women affected by the current table led to the need for research on satisfaction with basic health services. The purpose of this study is; Information on the satisfaction of basic health services of Syrian women who came to Turkey and who took refuge in Burdur district of province.

\section{Materials and Methods}

A questionnaire study consisting of 20 questions was carried out by researchers to collect information about the satisfaction of Syrian women from basic health services, who came to Turkey and took refuge in the Burdur province of Bucak. Participation in the survey was specifically stated to be based on volunteerism and was sincerely requested to fill out. The questionnaire was asked about the participants' socioeconomic status, the number of children and the way of delivery, the level of knowledge about the evaluations of the hospitals. Survey questions were directed to Syrian women with the help of an interpreter and data were collected. The survey sample consisted of 50 women, of whom 7 gave up participating in the survey and the research was completed with 43 women. The data was acquired by the researcher between October 2016 and January 2017 in a face-to-face interview method, explaining the aim of the research to the Syrian women who were part of the research sampling. Written permission from Mehmet Akif Ersoy University Ethical Committee (GO 2016/48) was obtained. The objective of the research was explained to the participants and written permission was received from those agreeing to participate in the research.

\section{Results}

The mean age of 43 women who participated in the survey was $30.19 \pm 3.12$. The average number of children of the 43 women participating in the survey was found to be $2.7 \pm 0.6$ (max: 7 ). Thirty-four $(74.4 \%)$ of the women identified hospital conditions as good. In terms of health services, 22 women $(52.2 \%)$ stated that they did not see any difference between Syria and our country. About 30 women $(69.8 \%)$ stated that they can provide comfortably. The number of mothers giving birth in our country is $38(88.4 \%)$. Twenty-six of the women $(60.4 \%)$ did not use any family planning method. The number of mothers who did not vaccinate their children was found as $5(11.6 \%) .97 \%$ of the women stated that they want to go back to their country. 
Polat, M., Dilek, G. A., Demir Barutcu, C. \& Köksoy, S. (2017). The level of satisfaction of primary health services evaluation about Syrian women refugees who took refuge in the town Bucak. Journal of Human Sciences, 14(2), 1861-1864. doi:10.14687/jhs.v14i2.4457

\section{Discussion}

With the increase in violence in Syria, there is an influx of asylum seekers to Turkey starting from the day when the citizens of Syria abandoned their country and began to take refuge in neighboring countries. Numerous asylum seekers who come to the southern border of Turkey due to the violence explosion that started in the middle of March 2011 in Syria bring problems with them (Zencir \& Davas, 2014; Tunç, 2015, s. 45). The most important of the problems is that millions of people who cannot reach the basic needs like food, water, electricity, fuel or medical equipment due to war give life struggle in hunger, disease and poverty. Increasing number of asylum seekers especially in the southern border of our country cause problems in socio-economic problems as well as health system (Özcan, 2005). Factors such as lack of adequate health institutions and human power in these regions, inadequate feeding of asylum seekers, encountering language barrier, lack of health insurance, social and psychological stress negatively affects health problems of asylum seekers and affects their health negatively. Because these people who are laid in the poverty of the poverty are faced with important health risks due to the unhealthy living conditions in the pre-immigration environments, the immigration environment and the immigration environments (AFAD, 2014; Aksoy, 2012, s. 298). The epidemic effects increase with the intervention of the immunization programs of health services and the efforts to protect from diseases. For example, measles disease began to spread from Asiatic asylum seekers who escaped from Syria and took refuge in Turkey. In Turkey, 349 cases of measles were observed in 2012 and it is stated that this number has reached 20 after the influx of Syrian asylum seekers (Ataman, 2015). In our study, the proportion of mothers who did not vaccinate their children was found to be 11.6\%. World Health Organization (WHO), Jordan, Lebanon, Iraq and Turkey in the villages of the Syrians, measles, tuberculosis and various infectious skin diseases are noted. The Turkish Nationalities Union (TTB) also warns that the asylum seekers' migration to Syria is thought to be effective in the dissemination of girl-witness cases (Altındiş, 2013; Erdoğan, 2014). It is necessary to examine the influence of the Syrians on basic services in terms of both Syrians and the public. In this regard, the most common problem areas of the Syrians are in the field of housing, health and education (Gün \& Bayraktar, 2008). They live in camps of Syrians who have access to the health service district. The group who live outside the camp and make up the majority are given free access to health services and medicines if they register. Those who fail to register for various reasons, no rights can never be achieved. Syrians constitute the strengths of the basic health services provided in the opportunities that provided about the size. On the other hand, public hospitals in the border cities of service, a total of $30 \%$ and $40 \%$ from health workers to serve among the Syrians at a rate and capacity in terms of physical conditions, there is a problem (Kanat \& Üstün, 2015, s. 60). The intensity of along with this situation the Syrians are one of the weaknesses of the impact on health services. Not seen in Turkey (polio, leishmaniasis, measles, decreasing the number of very, etc.) the reappearance of certain diseases to the health of the community of the negative impact should be addressed (Oytun \& Gündoğar, 2015).

\section{Conclusion}

As a result; the battles, as they were in the past, remain an important public health update today. There are still many conflicts in many different parts of the world. The most important groups affected by war and conflict environments are the vast majority of civilians formed by women and children. It is the general outcome of our work that refugees are lacking in receiving basic health care. The lack of family planning, vaccination needs to be addressed. We think that the attitudes of the mothers who do not vaccinate, especially in order to prevent infectious diseases, should be changed.

Limitations of the Study: It is important for Syrian women refugees to assess their level of satisfaction of primary health services. Regular, systematic assessments will help health 
Polat, M., Dilek, G. A., Demir Barutcu, C. \& Köksoy, S. (2017). The level of satisfaction of primary health services evaluation about Syrian women refugees who took refuge in the town Bucak. Journal of Human Sciences, 14(2), 1861-1864. doi:10.14687/jhs.v14i2.4457

professionals to identify risk groups as early as possible. Future research should assess the different parameters for refugees and should be evaluated more extensively with a larger sample.

Acknowledgement: The authors thank all Syrian women refugees who participated in this study.

\section{References}

AFAD (Disaster and Emergency Management Authority), (2014). Syrian Women's Report in Turkey. Ankara.

Aksoy, Z. (2012). International Migration And Intercultural Communication. The Journal of International Social Research, 5(20), 292-303.

Altındiş, M. (2013). Refugees, epidemics and protection in Turkey. Journal of Health Thinking and Medical Culture 28, 64-67.

Ataman, H. (2015). Refugee Behaviour and Its Social Effects: An Assessment of Syrians in Turkey?. Opinion Journal, 88, İstanbul.

Baydar, S. O. (2012). Refugees, Asylum-seekers, Illegal Immigrants and Their Effects on the Country Economy in the World and Turkey-2. Unofficial World Atlas.

Erdoğan, M. M. (2014). Syrian in Turkey: Social Acceptance and Adaptation Survey.

Gün, Z.ve Bayraktar, F. (2008). The Role of Migration on Adjustment of Adolescents in Turkey. Turkish Journal of Psychiatry, 19(2), 167-176.

Kanat, K.B. ve Ustun, K. (2015). Turkey's Syrian Refugees. SETA Publications 49, 55-64.

Koruk, I. (2013). Refugee Rights and Public Health Management. Retrieved 15 January 2016 from http://www.klimik.org.tr/wp-content/uploads/2013/03/IBRAHIMkORUK.pdf.

Oytun, O. ve Gündoğar, S. S. (2015). Report on the Effects of Syrian Asylum Seekers to Turkey . ORSAMTESEV Report No:195, Ankara.

Özcan, M. (2005). European Union Asylum Law: Emergence of a Common Asylum Law. International, Strategic Research Institutions Publications, Ankara.

Tunç A. Ş (2015). Refugee Behaviour and Its Social Effects: An Assessment of Syrians in Turkey. Journal of TES AM Academy, 2 (2), 29 - 63.

USAK, International Strategic Research Institutes, Social Studies Foundation (2013). Report No:13-04

UNHCR, (2011). Global Trends Report. The UN Refugee Agency, Retrieved 15 December 2016 from http://unhcr.org/4fd687f9.html.

Zencir, M. ve Davas, A. (2014). Syrian Refugees and Health Services Report. Ankara: Turkish Nationalities Union ISBN 978-605-5867-79-9.s 